desirable. How can we more readily secure this information and measure the results of our methods of remedying conditions unfavorable to health than by a follow-up system which includes the investigation of home conditions, the medical-social education of parents and medical supervision and periodic inspection? To be of real value, this system must apply to all cases, not to occasional or selected cases; it must be a continuous part of the hospital routine; and, finally it must not be merely a negative factor, finding out the patient's condition at periodical intervals after discharge, but a positive factor, exercising control over conditions. The cost of such a follow-up system adds only one tenth to our hospital budget.

Prevention is cheaper than cure. If we can by means of a follow-up system determine and measure our problems and secure results, this cost should be turned into actual saving to the hospital by decreasing the number of readmissions.

Does not our knowledge of preventive medicine and such clinical experience and statistical evidence as this study discloses indicate that a follow-up system to show problems and secure and determine results is an essential part of the equipment required to produce and measure hospital efficiency in its twentieth century interpretation?

\section{THE EXPERIMENTAL TRANSPLANTATION OF THE EPIPHYSIS}

\section{WITH OBSERVATIONS ON THE LONGITUDINAL GROWTH OF BONE *}

\section{S. L. HAAS, M.D SAN FRANCISCO}

No subject in bone surgery has been so extensively investigated during the last few years as has that concerning the transplantation of bone. As a consequence of these studies certain of the resulting changes that take place after transplantation have been solved, but there is still lacking a uniform agreement relative to some of these processes. From the clinical standpoint, however, there is a universal acceptance as to the successful applications of bone transplantations. Thus for the filling in of a bone defect, for the curing of a pseudo-arthrosis, for the producing of an ankylosis of the spine or the joint, and for the correcting of a nasal and other deformity, the transplantation of bone serves a very definite purpose. In all of these conditions a piece of diaphyseal bone with its periosteum is selected for the transplantation material.

From a practical standpoint it is not absolutely imperative that a transplant remain entirely alive and its cells be capable of proliferation, although if it possess these properties it is more likely to be successful. If it be demanded, in addition to the mere passive function of filling in a defect or acting as a framework for the ingrowth of neighboring bone, that the transplant must also possess the active propcrty of increasing in length, within itself, then it is absolutely essential that its cells remain alive and be capable of dividing and extending in a linear direction.

* From the Pathological Laboratory and the Surgical Pathologica Latoratory of Leland Stanford, Jr, University School of Medicin * Read before the Section on Orthopedic Surgery at the Sixty Sixth Annual Session of the American Medical Association, San Irancisen, June. 1915.
As the longitudinal growth of bone is due to proliferation of the tissue at and adjoining the epiphyseal cartilage, it is necessary to include that part of bone in a transplant when an increase in length is desired. It is not alone sufficient that the cells of the part remain alive after transplantation, but they must retain their ability to multiply in such a manner as to further increase the length growth. In such a case there is an additional requirement of the transplanted tissue besides the mere supporting property of diaphyseal bone. This additional requirement demands that the tissue retain the active function and inherent property of the normal epiphysis to increase the length of bone. The epiphysis is to be considered as a highly specialized tissue which will undoubtedly respond to the general laws of regeneration and transplantation, in that the more highly differentiated the tissue and the more dependent on its blood, vascular, lymphatic and trophic nerve supply it be, the less likely is the possibility of the successful transplantation of that particular tissue. On the independency of the epiphysis to withstand these losses depends its functional transplantability.

It is surprising that this interesting and complex subject has not been more extensively investigated. Aside from the scientific problems connected with such a study there are offered numerous opportunities for clinical applications of a successful method. Instances of such possibilities are found in cases of destruction of the epiphysis following tuberculosis and acute infection of the bones in early childhood; in certain neoplasms necessitating the removal of the epiphysis, in congenital shortening of the limbs, in defcctive growth after infantile paralysis, in destructive traumatic injuries of the epiphysis, in rachitis, and in congenital dislocations of the hip. Since the reports of transplantation of joints by Lexer, Kuttner and others, it would be very important to know the behavior of the epiphysis after transplantation before attempting such procedures on growing individuals.

From the optimistic conclusions of Rehn and Wakabajashi ${ }^{1}$ in 1912 , one would be entirely justified in attempting to perform the transplantation of the epiphysis in order to correct any of the above-mentioned conditions when there was loss of the function or the destruction of the epiphysis. These investigators performed homoplastic transplantations on two months old rabbits of the same brood, using the upper end of the radius including the epiphyseal cartilage. They concluded from their experiments that the epiphyseal cartilage after homoplastic transplantations retains its full life properties, showing no evidence of degeneration, and from the very first took over the function of its resected predecessor. These conclusions cannot be accepted without comment, as they were drawn from experiments in which the proximal part of the radius was transplanted, the epiphysis of which shares only a small part in the production of the length growth and therefore a failure of its functions would not be very noticeable when compared with the marked activity of the distal epiphysis. They have relied entirely on a comparison of the roentgenograms of the two feet which were only taken at the conclusion of the experiment in order to determine the variation in growth. As the place of union was evident in

1. Rehn, E., and Wakabajashi: Die homoplastische Transplantation des Intermediarknorpels im Thierexperiment, Arch. f. klin. Chir., 1912, 
their expermients they could have easily determined, by means of measuring at the time of the operation and at conclusion of the experiments, whether or not the transplanted piece actually increased in length.

In the same year appeared Axhausen's ${ }^{2}$ experimental work in which he performed homotransplantations in young rabbits. He used the lower end of the femur, thin sheets of epiphyseal cartilage, and patella, for his transplantation material and transplanted them under the skin. He found that the greater part of the epiphysis died and that only that part remained alive which was situated beneath the perichondrium. In the middle part of the epiphysis he noticed degenerated areas, and he claimed that ossification took place only in the cartilage that remained alive. In these experiments there was lacking functional stimulation, and for that reason the results are open to criticism.

The results of Axhausen's work were diametrically opposite to Rehn and Wakabajashi. On the other hand, they agreed to a certain extent, with those of Enderlen ${ }^{3}$ and Helferich. ${ }^{4}$ The latter investigators, who were the pioneer workers on this particular subject, performed experiments of epiphyseal transplantations as early as 1899 . They reimplanted the epiphysis in rabbits, using the lower epiphyseal cartilage of the ulna with an adjoining piece of the epiphysis and the diaphysis. Helferich, from the macroscopic findings, reported that the epiphyseal cartilage under favorable conditions need not lose its property of producing length growth. A lessening of this property might be observed but there was not an entire loss. Enderlen, who made the microscopic study of these preparations, reported that the reimplanted epiphyseal cartilage retained its vitality to a large extent. In agreement with Axhausen he noticed that the best maintained were those parts near the perichondritum, while those at the center showed evidence of degeneration. There was an increase in width of the epiphyseal cartilage due to an ossification coming from the living cartilage. The, ulna was retarded in growth and, on that account, caused a bending of the radius.

Aside from the investigations of $Z_{0 p p i}{ }^{5}$ who found in his autotransplantation of the epiphysis a regular healing in and the formation of new bone, while in his heteroplastic transplantations there resulted a complete failure; and the studies of Galcarzi, ${ }^{6}$ who found that there was a calcification of the epiphysis and loss of function in both auto and homotransplantation, there have been no other attempts to solve this problem prior to the beginning of the present work. During the last year several additional articles have appeared and they will be briefly reviewed.

Of these recent articles the first that appeared was by von Tappeiner ${ }^{7}$ who performed reimplantations and homotransplantations on dogs six and twelve weeks of age, using the distal half of the metatarsal. In his reimplantations he found that there was no

2. Axhausen, G.: Ueber den histologischen Vorgang bei der Transplantation von Gelenkenden, in besondere über die Transplantationsfähigkeit von Gelenkknorpel und Epiphysenknorpel, Arch. f. klin. Chir., 1912 , xcix, 1.

3. Enderlen: Zur Reimplantation des resecirten Intermediärknorpels beim Kaninchen, Deutsch. Ztschr. f. Chir., 1899, li, 574.

4. Helferich: Versuche uber die Transplantation des Intermediärknorpels wachsender Röhrenknochen, Deutsch. Ztschr. f. Chir., 1899, li, 564.

5. Zoppi: Q:1oted by Rehn and Wakabajashi, Note 1.

6. Galcarzi: Quoted by Rehn and Wakabajashi, Note 1.

7. Von Tappeiner, Fr. H.: Studien zur Frage der Transplantations fähigkeit des Lpiphysenkrorpels und des Gelenkknorpels, Ztschr. f. d. ges. exper. Mied., 1913, i, 491. disturbance in length growth even after six months, while in his homotransplantations he noticed a regular increasing shortening which was proportional to the length of time that had elapsed. He emphasized the importance of early function, and states that the younger the animal the less the amount of shortening. From his homotransplantations he concluded that for clinical applications the transplantations of the epiphysis is unsuccessful.

A short time later there appeared an extensive article by Obata $^{8}$ who performed on rabbits reimplantations, autotransplantations and homotransplantations of the entire metatarsophalangeal joint with either a part or an entire metatarsal and phalanx. In some experiments the transplants were made from the dead animal either with or without keeping for a time in salt solution. He also repeated the experiments of Rehn and Wakabajashi by transplanting the head of the radius from one animal to another. In his cor:clusions he stated that there was more or less shortening in all the cases, but that it was most marked in the homotransplantations. A bony union occurred in all the experiments except in homotransplantations, in which condition a pseudo-arthrosis resulted. In homotransplantations of the head of the radius he found only a slight degree of shortening. He does not agree with Rehn and Wakabajashi that this transplanted epiphysis functionated, but ascribes the evening up of growth to more extensive proliferation of the distal epiphysis. In the transplantations from the dead animal he noticed no evidence of growth and found with one exception that a pseudo-arthrosis occurred.

The next article that appeared was by Heller, ${ }^{9}$ who carried out reimplantations of the distal epiphysis of the radius and ulna as well as homotransplantations between related and nonrelated rabbits. He also made a few reimplantations and autotransplantations in goats. He reported that the epiphysis did not keep up its normal length growth in any of the forty-five experiments in which the epiphyseal cartilage $w \star s$ transplanted in the form of half joints. The least amount of shortening took place in the reimplantations, while a greater degree occurred in homoplastic transplants, most marked in the nonrelated animals. In homoplastic transplantation he believed there was a complete cessation in function of the epiphysis, and he ascribed all growths to the nonoperated proximal epiphysis. From his experience with goats, because of the more marked degree of shortening, he concludes that the larger the transplant and the greater the size of the animal, the more marked will be the shortening. In concluding, he said that in autotransplantations there was a lively regeneration of the epiphyseal cartilage from the perichondrium and that a not inconsiderable amount of bone apposition could be recognized, but nevertheless the bone growth remained checked and could not be utilized for practical purposes, especially so in cases of homotransplantations. He thinks that the most favorable conditions for the transplantation of the epiphyseal cartilage would be in the form of a thin sheet without adhering bone particles, so that it could? come more directly in contact with the nourishing

8. Obata, K.: Ueber Transplantation von Gelenken bei jungen Tieren, mit besonderer Berücksichtigung des Verhaltens des Intermediürkmor-

pels. Beitr. z. path. Anat. u. z. allg. Path., 1914, xlix, 1.
9. Heller: Experimentelle Untersuchungen uber die Transplantation des Intermediärknorpels in Form der halbseitigen Gelenktransplantation, Arch. f, klin. Chir., 1914, civ, 843 . 
fluids of the bo:ly. In a postscript he added that in his more recent experiments on two months old animals, in which after autotransplantations of the epiphyseal cartilage in the form of very thin sheets, he found almost a normal growth. The exact details of these experiments are not given, so one cannot conjecture on the cause of the variations from his previous results.

The most recent article is by Minoura ${ }^{10}$ on the transplantation of metatarsophalangeal joints of two months old rabbits into the soft tissues. Either the whole or half joint that was either intact or split longitudinally was transplanted into the back, subcutaneous tissue, liver, or abdominal cavity of the same or different animal. In some instances the joint was placed in a Ringer's solution before transplantation or was removed from a dead animal. He observed that the transplanted joints became encapsulated after one or two weeks. The healing always appeared the same whether it was in the abdominal cavity, subcutaneous tissue, liver, or the muscle. The longitudinally split half joints underwent quicker organization than the unsplit and resorption took place more rapidl; when the parts were allowed to remain in Ringer's solution. He concluded that autotransplantation was siperior to homotransplantation and that the substitution processes were more active, quicker and intense, and that autoregeneration was more significant and continued for a longer period. Not much difference was noticed between transplants from the dead or from the living animal. In no case after transplantation, even in autotransplantation, was there any regular growth of the epiphyseal cartilage (only an irregular proliferation was found in the periphery) and in no case was there a lengthening of the transplanted joint. In comparing these experiments with those in which the transplantations were made into bone defects, it was noticed that the new formation was less evident, the degeneration appeared earlier in the new-formed tissue, and the resorption played a greater rôle, as in these cases the functional requirements of the respective tissue was lacking.

The prevailing opinions of these investigators indicate that the epiphyseal cartilage after transplantation loses more or less of its power to proliferate and thereby to increase the length of bone. In general they found considerable growth in reimplantations, less in autotransplantations, and practically none in homotransplantations. The greater the variations in the species the greater will be the growth disturbances. None of the authors agreed with Rehn and Wakabajashi in that there was no disturbance in growth after homotransplantation of the epiphysis.

All of the seventy-five experiments of this series were performed on dogs, the same animal often being used for two or more observations.

The majority of the animals were from cone and a half to four months of age at the time of operation. In some animals the ages were not definitely known. They showed a definite growth after operation, but the metacarpals had not changed in length. This paradoxical condition can be explained by assuming that growth ceases in the metacarpals before it does in the longer bones.

The metacarpal and metatarsals were selected because they possessed but one epiphysis situated at

10. Minoura, M.: Studien über Ge:enktransplantation (inkl. Intermediarknorpel) in Weichteile, Frankfurter Ztschr. f. Path., 8, 1914, xv, $39 \%$. the distal end of the bone and any growth which occurred could only be ascribed to proliferation at that particular epiphyseal cartilage. These bones were also easily measured at the time of operation and any change in length could readily be determined at the conclusion of the experiment. Another advantage in using these particular bones is that the adjoining bones serve as a natural splint.

\section{METHOD OF OPERATION}

All of the opcrations were performed under general ether anesthesia. 'The extremity was shaved and painted twice with tincture of iodin and the operation carried out with the usual aseptic technic.

The incision was made on the dorsal surface of the foot and special precautions were taken in order to preserve the normal vascular and nerve supply to that particular region.

In removing the segment to be transplanted special care was exercised so as not to injure the epiphyseal cartilage. In the very young animals a sharp knife was used, while in the older animals a small saw was necessary to sever the bony connections of the transplantation material.

The small transplants were anchored in place by means of an X-shaped silk suture, while the larger pieces were reinforced by an additional suture passed through the cortex of the diaphysis of each fragment. The total length of the operated and adjoining bones, also the removed and implanted segments were carefully measured. The wound was closed in layers and the foot encased in a plaster dressing, which was removed in from fourteen to twenty-one days. The animal was allowed its freedom from the start. Primary healing resulted in all but two cases.

At the conclusion of the experiment a roentgenogram was taken of the corresponding two feet. Then the foot was dissected and measurements made of all the metacarpals of both the operated and the normal foot. One half of a longitudinal section was preserved in Kaiserling's solution and the remaining part placed in Orth's fluid for further study.

It will be possible to give in this paper only the observations of the changes in growth following the various operative procedures.

In the interpretation of the results certain standards of comparison have been adopted in order to determine the various changes. The two inner metacarpals have been found from repeated observation on normal extremities to be of equal length or within $1 \mathrm{~mm}$. of each other. It has also been noticed that the corresponding bones of each foot are practically of the same length. Thus there is a definite standard of comparison by means of which any change in growth may be calculated.

The following sets of experiments were performed:

1. Reimplantation of an entire metacarpal or metatarsal: In these experiments the entire bone with its articular surfaces and periosteum intact was raised from its position and immediately replaced. Table 1 shows the results.

Conclusion: After reimplantations of entire metacarpals or metatarsals, in growing animals, there is complete cessation of the growing function of the epiphysis. 
TABLE 1.-REIMPLANTATION OF AN ENTIRE METACARPAL OR METATARSAL

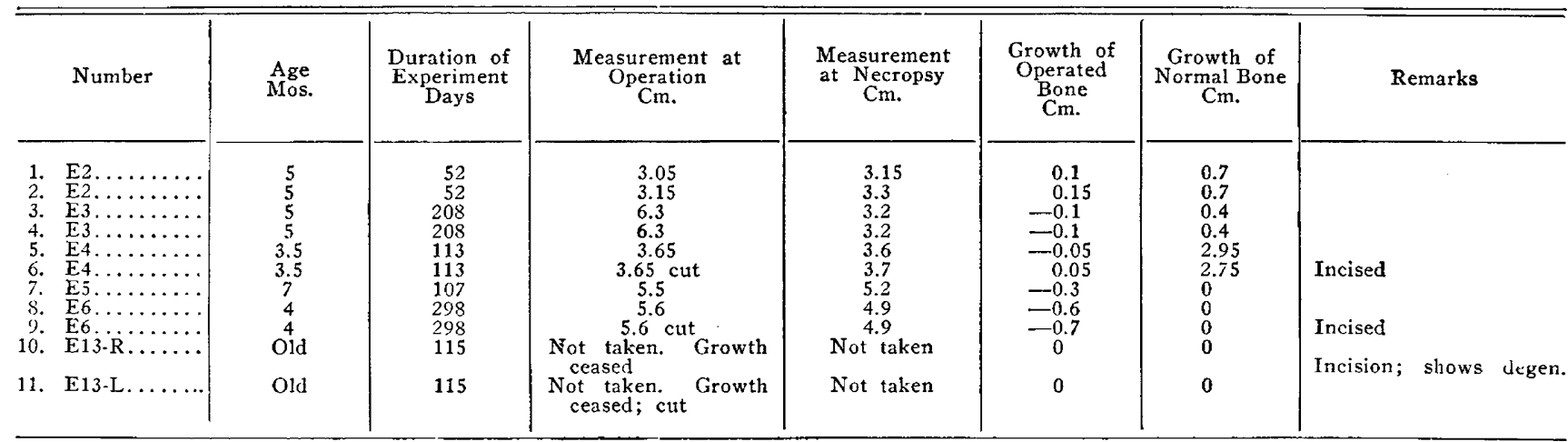

TABLE 2.-AUTOTRANSPLANTATION OF AN ENTIRE METACARPAL OR METATARSAL

\begin{tabular}{|c|c|c|c|c|c|c|c|}
\hline Nuniber & $\begin{array}{l}\text { Age } \\
\text { Mos. }\end{array}$ & $\begin{array}{c}\text { Duration of } \\
\text { Experiment } \\
\text { Days }\end{array}$ & $\begin{array}{c}\text { Measurement at } \\
\text { Operation } \\
\text { Cm. }\end{array}$ & $\begin{array}{l}\text { Measurement } \\
\text { at Necropsy } \\
\mathrm{Cm} .\end{array}$ & $\begin{array}{c}\text { Growth of } \\
\text { Operated } \\
\text { Bone } \\
\text { Cm. }\end{array}$ & $\begin{array}{c}\text { Growth of } \\
\text { Normal } \\
\text { Bone } \\
\text { Cm. }\end{array}$ & Remarks \\
\hline 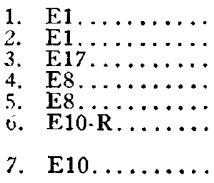 & $\begin{array}{r}5 \\
5 \\
9 \\
6 \\
5 \\
3.5 \\
3.5\end{array}$ & $\begin{array}{r}109 \\
109 \\
36 \\
91 \\
91 \\
89\end{array}$ & $\begin{array}{l}6.9 \text { cut } \\
6.9 \\
6.7 \text { cut } \\
6.7 \text { right } \\
6.7 \text { left } \\
4.8 \text { cut } \\
4.8\end{array}$ & $\begin{array}{l}1.5 \\
6.6 \\
6.1 \\
6.8 \\
6.4 \\
4.3 \\
4.3\end{array}$ & $\begin{array}{r}-5.4 \\
-0.3 \\
-0.5 \\
0.1 \\
-0.3 \\
-0.5 \\
-0.5\end{array}$ & $\begin{array}{r}0 \\
0 \\
0.3 \\
0 \\
0.2 \\
0\end{array}$ & $\begin{array}{l}\text { Cut off end } \\
\text { Long incis. at both ends } \\
\text { Incision; showed evi- } \\
\text { dence of degeneration }\end{array}$ \\
\hline
\end{tabular}

TABLE 3.-REIMPLANTATION OF SPLIT METACARPAL OR NETATARSAL

\begin{tabular}{|c|c|c|c|c|c|c|c|}
\hline Number & $\begin{array}{l}\text { Age } \\
\text { Mos. }\end{array}$ & $\begin{array}{c}\text { Duration of } \\
\text { Experiment } \\
\text { Days }\end{array}$ & $\begin{array}{c}\text { Measurement at } \\
\text { Operation } \\
\mathrm{Cm} .\end{array}$ & $\begin{array}{l}\text { Measurement } \\
\text { at Necropsy } \\
\text { Cm. }\end{array}$ & $\begin{array}{l}\text { Growth of } \\
\text { Operated } \\
\text { Bone } \\
\text { Cm. }\end{array}$ & $\begin{array}{l}\text { Growth of } \\
\text { Operated } \\
\text { Bone } \\
\text { Cm. }\end{array}$ & Remarks \\
\hline $\begin{array}{ll}\text { 1. } & \text { E9....... } \\
2 . & \mathrm{E} 14-6 \ldots \ldots \ldots \\
\text { 3. } & \mathrm{E} 15 \ldots \ldots \ldots \\
\text { 4. } & \mathrm{E} 18.2 \ldots \ldots \ldots\end{array}$ & $\begin{array}{c}? \\
4.5 \\
6 \\
6\end{array}$ & $\begin{array}{r}31 \\
237 \\
38 \\
223\end{array}$ & $\begin{array}{l}5.7 \\
5.9 \\
5.8 \\
6.05\end{array}$ & $\begin{array}{l}5.6 \\
5.8 \\
5.8 \\
3.3\end{array}$ & $\begin{array}{l}-0.1 \\
-0.1 \\
0 \\
-2.8\end{array}$ & $\begin{array}{l}0 \\
0 \\
0 \\
0\end{array}$ & Consid. change in marrow \\
\hline
\end{tabular}

TABLE 4.-AUTOTRANSPLANTATION OF SPLIT METACARPAL OR METATARSAL

\begin{tabular}{|c|c|c|c|c|c|c|c|}
\hline Number & $\begin{array}{l}\text { Age } \\
\text { Mos. }\end{array}$ & $\begin{array}{l}\text { Duration of } \\
\text { Experiment } \\
\text { Days }\end{array}$ & $\begin{array}{c}\text { Measurement at } \\
\text { Operation } \\
\mathrm{Cm} .\end{array}$ & $\begin{array}{l}\text { Measurement } \\
\text { at Necropsy } \\
\text { Cm. }\end{array}$ & $\begin{array}{l}\text { Growth of } \\
\text { Operated } \\
\text { Bone } \\
\text { Cm. }\end{array}$ & $\begin{array}{c}\text { Growth of } \\
\text { Normal } \\
\text { Bone } \\
\text { Cm. }\end{array}$ & Remarks \\
\hline $\begin{array}{l}\text { 1. } \\
\text { 2. } \\
\text { E17 } 12, \ldots \ldots \ldots\end{array}$ & Very old & $\begin{array}{r}235 \\
36\end{array}$ & $\stackrel{?}{6.7}$ & $\begin{array}{l}6.1 \\
6.1\end{array}$ & $\begin{array}{l}-0.2 \\
-0.6\end{array}$ & $\begin{array}{l}0 \\
0.4\end{array}$ & $\begin{array}{l}\text { Incised degen. } \\
\text { Incised end necrotic }\end{array}$ \\
\hline
\end{tabular}

TABLE 5.-REIMPLANTATION OF THE EPIPHYSEAL CARTILAGE

\begin{tabular}{|c|c|c|c|c|c|c|}
\hline Number & $\begin{array}{l}\text { Age } \\
\text { Mos. }\end{array}$ & $\begin{array}{l}\text { Duration of } \\
\text { Experiment } \\
\text { Days }\end{array}$ & $\begin{array}{c}\text { Measurement at } \\
\text { Operation } \\
\mathrm{Cm} .\end{array}$ & $\begin{array}{c}\text { Measurement at } \\
\text { Necropsy } \\
\text { Cm. }\end{array}$ & $\begin{array}{c}\text { Growth of } \\
\text { Operated Bone } \\
\text { Cm. }\end{array}$ & $\begin{array}{l}\text { Growth of } \\
\text { Normal Bone } \\
\mathrm{Cm} .\end{array}$ \\
\hline $\begin{array}{ll}1 . & \mathrm{E} 14-6 \ldots \ldots \ldots \\
2 . & \mathrm{E} 23-13 \ldots \ldots \\
\text { 3. } & \mathrm{E} 24-14 \ldots \ldots \\
4 . & \mathrm{E} 33-44 \ldots \ldots \\
\text { 5. } & \mathrm{E} 38.26 \ldots \ldots \\
6 & \mathrm{E} 41-39 \ldots \ldots\end{array}$ & $\begin{array}{l}4.5 \\
1.5 \\
? \\
1.5 \\
4.0 \\
5.0\end{array}$ & $\begin{array}{r}37 \\
23 \\
4 \\
43 \\
55 \\
43\end{array}$ & $\begin{array}{l}5.9 \\
3.9 \\
3.6 \\
2.7 \\
4.4 \\
4.55\end{array}$ & $\begin{array}{l}5.7 \\
4.1 \\
3.8 \\
2.8 \\
4.2 \\
4.5\end{array}$ & $\begin{array}{r}-0.2 \\
0.2 \\
0.2 \\
0.1 \\
-0.2 \\
-0.05\end{array}$ & $\begin{array}{l}0 \\
0.4 \\
0 \\
0.7 \\
0.1 \\
0.5\end{array}$ \\
\hline
\end{tabular}

TABLE 6.-AUTOTRANSPLANTATION OF TIIE EPIPHYSEAL CARTILAGE

\begin{tabular}{|c|c|c|c|c|c|c|c|}
\hline Number & $\begin{array}{l}\text { Age } \\
\text { Mos. }\end{array}$ & $\begin{array}{l}\text { Duration of } \\
\text { Experiment } \\
\text { Days }\end{array}$ & $\begin{array}{c}\text { Measurement at } \\
\text { Operation } \\
\text { Cm. }\end{array}$ & $\begin{array}{l}\text { Measurement } \\
\text { at Necropsy } \\
\text { Cm. }\end{array}$ & $\begin{array}{c}\text { Growth of } \\
\text { Operated } \\
\text { Bone } \\
\text { Cm. }\end{array}$ & $\begin{array}{c}\text { Growth of } \\
\text { Normal } \\
\text { Bone } \\
\text { Cm. }\end{array}$ & Remarks \\
\hline $\begin{array}{ll}\text { 1. } & \mathrm{E} 9-4 \ldots \ldots \ldots \\
\text { 2. } & \mathrm{E} 10-5 \ldots \ldots \ldots \\
\text { 3. } & \mathrm{E} 15-7 \ldots \ldots \ldots \\
\text { 4. } & \mathrm{E} 23-13-\mathrm{R} \ldots \ldots \\
\text { 5. } & \mathrm{E} 23-13-\mathrm{L} \ldots \ldots \\
\text { 6. } & \mathrm{E} 32-39-\mathrm{R} \ldots \ldots \\
\text { 7. } & \mathrm{E} 32-39-\mathrm{L} \ldots \ldots\end{array}$ & $\begin{array}{l}? \\
3.5 \\
6.0 \\
1.75 \\
1.75 \\
1.75 \\
1.75\end{array}$ & $\begin{array}{r}86 \\
89 \\
38 \\
23 \\
23 \\
136 \\
136\end{array}$ & $\begin{array}{l}5.1 \\
4.8 \\
5.8 \\
4.0 \\
3.6 \\
2.5 \\
2.55\end{array}$ & $\begin{array}{l}5.0 \\
4.5 \\
5.9 \\
4.2 \\
3.8 \\
2.85 \\
2.9\end{array}$ & $\begin{array}{l}0 \\
-0.3 \\
0 \\
\\
0.2 \\
0.2 \\
0.35 \\
0.35\end{array}$ & $\begin{array}{l}0 \\
0.1 \\
0 \\
0.6 \\
0.4 \\
1.4 \\
1.4\end{array}$ & $\begin{array}{l}\text { Piece inserted was } 0.75 \\
\text { mm. wider than that } \\
\text { removed }\end{array}$ \\
\hline
\end{tabular}


2. Autotransplantation of an Entire Metacarpal or Metatarsal: An entire bone was transplanted from one foot to another foot of the same animal. Results are given in Table 2 .

Conclusion: The transplanted bones not only failed to grow, but showed definite evidence of degeneration and decrease in length.

3. Reimplantation of Split Metacarpal: The reimplanted bone was divided longitudinally and reinserted. Results are given in Table 3 .

Conclusion: As these animals had reached the end of their growing period no observations can be made on the disturbances in growth lengthwise. Some of the bones showed definite evidence of absorption and decrease in length.
4. Autotransplantation of Split Metacarpal or Metatarsal: Before transplanting to another foot the bone was split longitudinaliy. Results are given in Table 4.

Conclusion: In the single observation in this group in which the animal showed evidence of growth in the normal bones there was a definite decrease in size of the transplant, showing that the splitting of the bonc had no favoring influence on the viability of the epiphysis.

5. Reimplantation of the Epiphyseal Cartilage: In this series of experiments the epiphyseal cartilage, including a piece of adjoining epiphysis and diaphysis. was excised and immediately reimplanted. Table 5 gives the results.

TABLE 7.-REIMPLANTATION OF VARYING LENGTHS OF THE EPIPHYSEAL END OF THE METACARPAL AND THE METATARSAL BONES

\begin{tabular}{|c|c|c|c|c|c|c|}
\hline Number & $\begin{array}{l}\text { Age } \\
\text { Mos. }\end{array}$ & $\begin{array}{l}\text { Duration of } \\
\text { Experiment } \\
\text { Days }\end{array}$ & $\underset{\mathrm{Cm} .}{\text { Measurement at Operation }}$ & $\begin{array}{c}\text { Measure- } \\
\text { ment at } \\
\text { Necropsy } \\
\text { Cm. }\end{array}$ & $\begin{array}{l}\text { Growth of } \\
\text { Operated } \\
\text { Bone } \\
\text { Cm. }\end{array}$ & $\begin{array}{c}\text { Growth of } \\
\text { Normal } \\
\text { Bone } \\
\text { Cm. }\end{array}$ \\
\hline 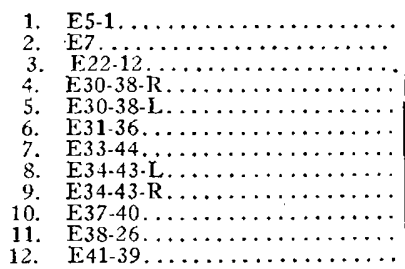 & $\begin{array}{r}5 \\
7 \\
1.5 \\
? \\
? \\
1.75 \\
1.5 \\
1.5 \\
1.5 \\
2 \\
4 \\
4.75\end{array}$ & $\begin{array}{r}107 \\
155 \\
22 \\
13 \\
13 \\
17 \\
44 \\
115 \\
115 \\
38 \\
85 \\
44\end{array}$ & $\begin{array}{ll}\text { Total } & 5.4 ; \text { resected } 1 / 2 \text { piece } 2.7 \\
\text { Total } & 7.4 \text { resected } 2 / 3 \text { piece } 4.4 \\
\text { Total } 4 ; \text { resected } 2 / 3 \text { piece } 2.55 \\
\text { Total } 2.4 ; \text { resected } 1 / 3 \text { piece } 0.7 \\
\text { Total } 2.4 ; \text { resected } 2 / 3 \text { piece } 1.8 \\
\text { Total } 2.5 ; \text { resected } 1 / 2 \text { piece } 1.25 \\
\text { Total } 2.7 \text { resected } 1 / 2 \text { piece } 1.5 \\
\text { Total } 2.8 ; \text { resected } 1 / 3 \text { piece } 1.1 \\
\text { Total } 2.8 ; \text { resected } 2 / 3 \text { piece } 2.0 \\
\text { Total } 3.05 ; \text { resected } 2 / 3 \text { piece } 2.3 \\
\text { Total } 4.5 ; \text { resected } 1 / 2 \text { piece } 2.25 \\
\text { Total } 4.4 ; \text { resected } 1 / 3 \text { piece } 1.8\end{array}$ & $\begin{array}{l}5.2 \\
3.7 * \\
3.9 \\
2.3 \\
2.5 \\
2.5 \\
2.7 \\
3.25 \\
2.95 \\
3.0 \\
4.2 \ddagger \\
4.3 \ddagger\end{array}$ & $\begin{array}{l}-0.2 \\
-3.7 \\
-0.1 \\
-0.1 \\
0.1 \\
0 \\
0 \\
0.45 \\
0.15 \\
0 \\
-0.3 \\
-0.1\end{array}$ & $\begin{array}{l}0 \\
0.3 \\
0.5 \\
0 \\
0 \\
0.1 \\
0.7 \\
1.20 \\
1.45 \\
0.3 \\
0 \\
0.5\end{array}$ \\
\hline
\end{tabular}

* Infection. † Bored holes-nonunion at operation. \$Nonunion.

TABLE 8-AUTOTRANSPLANTATION OF VARYING LENGTHS OF EPIPHYSEAL END OF METACARPAL AND METATARSAL BONES

\begin{tabular}{|c|c|c|c|c|c|c|}
\hline Number & $\begin{array}{c}\text { Age } \\
\text { Mos. }\end{array}$ & $\begin{array}{l}\text { Duration of } \\
\text { Experiment } \\
\text { Days }\end{array}$ & $\begin{array}{c}\text { Measurement at Operation } \\
\mathrm{Cm} .\end{array}$ & $\begin{array}{c}\text { Measure- } \\
\text { ment at } \\
\text { Necropsy } \\
\text { Cm. }\end{array}$ & $\begin{array}{l}\text { Growth of } \\
\text { Operated } \\
\text { Bone } \\
\text { Cm. }\end{array}$ & $\begin{array}{c}\text { Growth of } \\
\text { Normal } \\
\text { Bone } \\
\text { Cm. }\end{array}$ \\
\hline 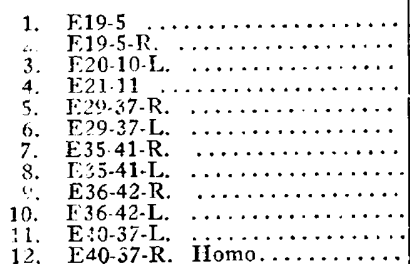 & $\begin{array}{l}5.0 \\
5.0 \\
1.5 \\
1.5 \\
2 \\
2 \\
1.75 \\
1.75 \\
1.75 \\
1.75 \\
5.5 \\
5.5\end{array}$ & $\begin{array}{r}34 \\
34 \\
25 \\
42 \\
143 \\
143 \\
111 \\
111 \\
43 \\
43 \\
43 \\
43\end{array}$ & 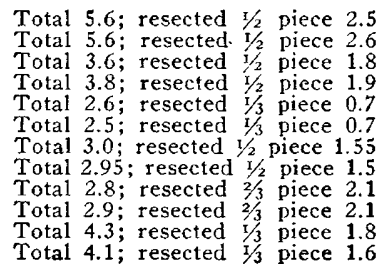 & $\begin{array}{l}5.65 \\
5.6 \\
3.6 \\
3.7 \\
2.75 \\
2.6 \\
3.0 \\
3.0 \\
2.9 \\
2.95 \\
4.2 \\
3.9\end{array}$ & $\begin{array}{l}0.05 \\
0 \\
0 \\
0 \\
0.15 \\
0.1 \\
0 \\
0 \\
0.1 \\
0.05 \\
0 \\
0\end{array}$ & $\begin{array}{l}0.6 \\
0.6 \\
0.5 \\
0.6 \\
1.15 \\
1.3 \\
1.6 \\
1.4 \\
0.55 \\
0.6 \\
0 \\
0.15\end{array}$ \\
\hline
\end{tabular}

TABLE 9.-TWO STAGE AUTOTRANSPLANTATION OF DIFFERENT LENGTHS OF THE EPIPHYSEAL END OF THE METACARPAL AND THE METATARSAL BONES

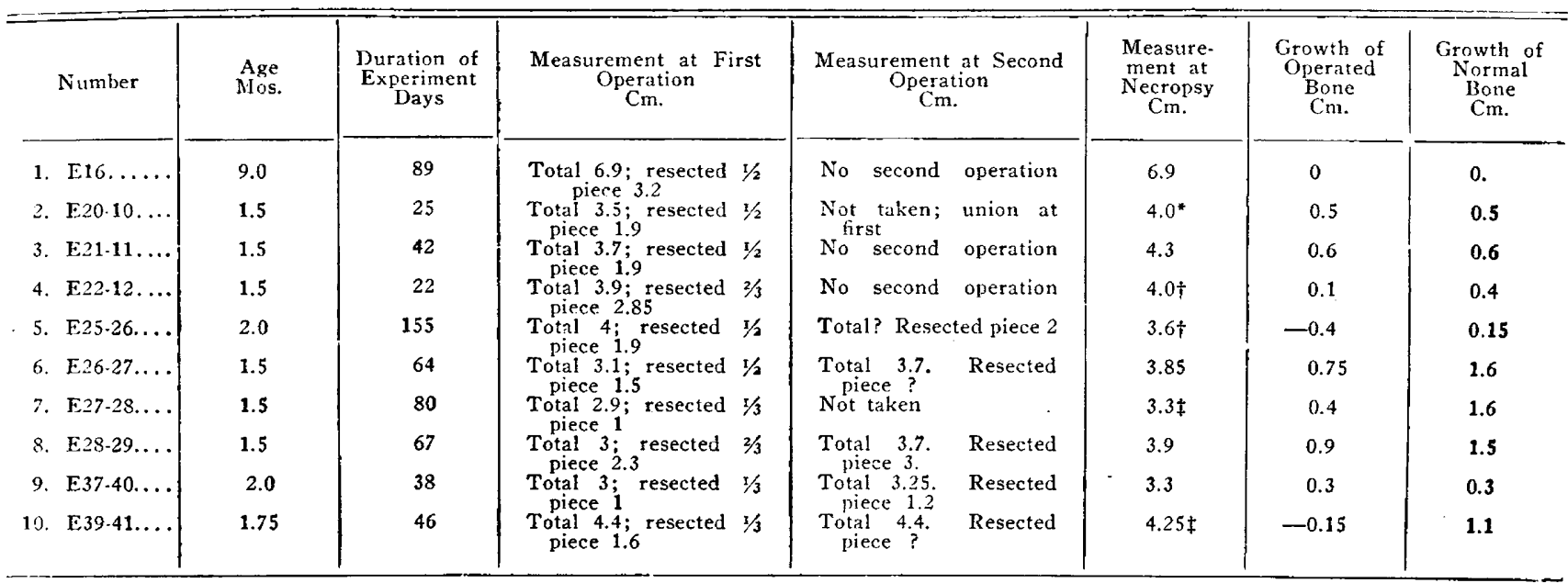

"Died two days after second operation. Nonunion at second operation. † Nonunion. $\ddagger$ Nonunion firit. 
Conclusion: In none of these experiments was there an increase of more than $2 \mathrm{~mm}$. in length since the operation, while the normal bones showed as much as $7 \mathrm{~mm}$. of growth. A difference of $2 \mathrm{~mm}$. in length is within the limits of error in measurement or lengthening due to failure of close approximation. After reimplantation of the epiphyseal cartilage there is at first a slight increase in length while at a later period there is a decrease in length.

6. Autotransplantation of the Epiphyseal Cartilage: In these experiments the resected epiphyseal cartilage was interchanged with a corresponding piece from a bone of the other foot. Results are noted in Table 6 .

Conclusion: With the exception of two experiments there was no definite evidence of increase in size after autotransplantation of the epiphyseal cartilage. In these two positive results the increase in size was very limited, being only $0.35 \mathrm{~cm}$. as compared with 1.4 $\mathrm{cm}$. of normal growth. On section of the bones the epiphysis of the operated bones showed definite signs of degeneration, while the epiphysis of the nonoperated bones presented a normal appearance. After autotransplantation of the epiphyseal cartilage its function to increase in a linear direction is entirely lost or only persists in a very limited degree.

7. Reimplantation of Varying Lengths of the Epiphyseal End of the Metacarpal and Metatarsal Bones: In this series of experiments one third, one half and two thirds of the epiphyseal end of the metacarpal was removed entirely from its normal bed and reinserted immediately in the same position. Results are noted in Table 7.

Conclusion: In none of these cases with the one exception of Experiment 8 E 34-43 L, was there any cvidence of increase in length growth. The exact reason for the incrcase in this experiment cannot be definitely determined. It is possible that for some special reason this particular epiphysis proliferated for a short time. In the gross specimen there is no evidence of cpiphyseal cartilage, so what growth occurted took place early and only for a limited time. In view of the large number of negative results this experiment cannot be definitely considered as indicating an active functioning of the transplanted epiphysis. Whether a long or short piece of bone was transplanted with the epiphysis was of no consequence as there was practically complete failure of the growth in every case. Incisions or boring of holes into the bone seem to hasten the degenerative processes.

8. Autotransplantation of Varying Lengths of the Epiphyseal End of the Metacarpal or Metatarsal: These experiments differ from those of the previous group (7) in that the segment of bone was interchanged with a corresponding segment from the opposite foot. Results are noted in Table 8.

Conclusion: There is a uniform failure of growth after autotransplantation of varying lengths of the epiphyseal end of the bones. The normal bones show a marked increase in length. Boring holes into transplants increases the degenerative processes.

9. Two Stage Autotransplantation of Different I engths of the Epiphyseal End of the Metacarpal or Metatarsal: In this set of experiments the distal onethird, one-half or two-thirds was united to the proximal two-thirds, one-half or one-third respectively of the adjoining metacarpal or metatarsal. After a sufficient length of time for union had elapsed a second operation was performed in which the distal segnent was entirely separated from its surrounding tissues, thereby completing the autotransplantation. Results . are shown in Table 9.

Conclusion: In this set of experiments there was evidence of almost normal growth up to the time of the second operation, but after severing the epiphyseal end from its surrounding tissue there was a marked diminution in growth. This shortening took place even when there was firm tuion with the normal proximal segment. It was noticed that in cases where nonunion occurred that there was more marked disturbances in growth - even in the first part of the experiment. Under these very favorable conditions for transplantation there was considerable diminution of the function of the epiphysis after transplantation.

\section{GENERAL CONCLUSIONS}

1. From the practically uniform failure of increase in length of the bones after transplantation of the epiphyseal cartilage, either alone or with an accompanying piece of the epiphysis and diaphysis, both in reimplantation and autotransplantation, it must be concluded that epiphyseal cartilage loses its power to functionate after such transplantations.

2. As the degenerative processes were more advanced in autotransplantation than in reimplantation, it can be almost certainly predicted that there would be a more marked degeneration in homotransplantation.

3 . Whether a small or large sized transplant was taken was of no consequence, as there was the same failure of growth in every instance. Incisions into the periosteum or boring holes into the cortex hastened the degenerative processes.

4. There was marked disturbance of growth following the two-stage autotransplantation, in spite of the fact that osseous union was secured before severing the epiphyseal transplant from its surrounding and nourishing tissues.

5. The epiphyseal cartilage must be considered as a very vulnerable tissue, its viability being directly dependent upon its blood supply.

Shreve Building.

\section{ABSTRACT OF DISCUSSION}

Dr. D. B. Phemister, Chicago: The finding of Dr. Haas that there is apparently no longitudinal growth through the epiphyscal cartilage after transplantation is very interesting. One would expect cartilage to live if any tissue lives when transplanted, because it is nourished by a lymphatic instearl of a blood vascular circulation. Hyaline articular cartilage covering the ends of bones is frequently detached with or without a portion of underlying bone and becomes a loose body in the joint. The bone cells, if any are present, always die and are absorbed, but the cartilage, receiving sufficient nutrition from the synovial fluid, remains alive indefinitely. The deeper cells which have a columnar arrangement slowly undergo necrosis. I have studied histologically ten or twelve such specimens of the various ages and have noted transformation of the superficial cartilage into fibrinous connective tissue in the older specimens. In one specimen that had been free in the joint for ten years there was proliferation of the cartilage and a connective tissue capsule had formed. The injury of the transplant resulting in disturbance of longitudinal growth might be either to the epiphyseal line or to the juxta-epiphyseal bone. The small amount of longitudinal growth occurring in some of his experiments might possibly be accounted for by longitudinal growth in the shaft itself. We see the shaft of a bone increase one-half an inch or more in length as a result of an inflammatory process, as syphilis or in osteitis deformans, where the epiphyseal lines are closed. Consequently, there 
is no reason why in the absence of the normal process of longitudinal growth, and where there is a great demand for it, the cells of the shaft should not proliferate and increase the length of the bone.

DR. J. T. Rugk, Philadelphia: I think the important lesson for us as practical orthopedic surgeons is the postponement of our operative work in this type of cases until adult life or until the expectation of any natural increase in growth is past. I know in my own experience I have becn sorely tempted at times to replace a very imperfect hip joint, in the case of congenital dislocation, or similar condition, with the head of the fibula, but have thus far refrained, and I shall continue to do so in the future. The lesson I liave learned from this experimental work of Dr. Haas has been of enormous importance.

Dr. Roland Mersendach, Buffalo: The work of Dr. Haas, in my opinion, is of great value. Although he has gotten some negative results, I think it touches on many things of value which will in the future give us a better understanding of one of the most important parts of the long bone; namely, the epiphysis. It may also assist in giving us a better understanding of the function of the epiphysis. I am particularly interested in this work because several years ago I did some research work on the chemical and mechanical stimulation of the epiphysis. In this work, I had occasion to observe the epiphysis both microscopically and macroscopically in about two hundred rabbits. In studying the epiphyseal and diaphyseal lines, it was interesting to see from the experimental work the close relation to the practical work; that is, the cases which we see daily that have interference of growth or which have stimulation of growth of the epiphysis. This work is really the fundamental source of all fracture and bone-graft work. I would like to ask Dr. Haas whether the transplant is divided from above or below the diaphyseal line. This will, I believe, change the results of the experiments materially. In my experiments I was able to stimulate and retard bone growth, depending on which part of the epiphyseal cartilage was attacked in the experiment. I have a few lantern slides which $I$ prepared for the Pan-American Congress which show sections of the epiphysis and epiphyseal line in different stages of stimulation. That is, that by either toxic or mechanical means it is possible to cause more bone to form in the region of the epiphyseal end of long bones, as in my experiments with tibias, or to almost cause an arrest of growth. One slide shows that by means of toxic agents it has been possible to cause the entire epiphyseal line to close at a much earlier period by months than normally. This explains, I believe, many of the cases which have focal infection at some part of the body that later on developed joint lesions, and in which the joints became deformed; also it explains the arrest of growth following fractures, and therefore $I$ think that an attempt to transplant the epiphysis dcpends largely on the point from which we take the transplant and the technic employed.

Dr. S. L. HaAs, San Francisco: As Dr. Phemister has mentioned, cartilage is a very resistant tissue. It is able to withstand a considerable amount of injury and is dependent on the surrounding tissues and fluids for its nourisinment. I have only studied a few microscopic preparations from these experiments and have found that the cartilage near the perichondrium remained alive. It is possible that some of this cartilage may continue to proliferate, but doubt if it would cause any decided increase in the length of the bone. There is a distinction between growth in length and increase in size. It was noticed in some of these experiments that there was a marked swelling about the epiphyseal cartilage without any increase in length, showing that although there was cell growth there was no purposeful longitudinal increase like the normal epiphyseal cartilage. It was merely the regular cell division and multiplication which manifested itself by spreading in the line of least resistance. It was shown in the old experiments of Hunter and Duhamel that the longitudinal growth of bone takes place only at the epiphyseal ends. In these experiments two pegs were driven into the diaphysis and in spite of an increase in length of the bone there was no change in the distance between the two pegs. As to the increase in length following destructive osteomyelitis, it might be due to the general wild multiplication during the processes of regeneration, which, being unrestricted, spread in all directions.

In regard to Dr. Meisenbach's question as to whether the transplantation was made above or below the epiphyseal. line, I presume he wishes to ascertain the relation of the incisions to the metaphysis, which is the most actively growing part of the bone. In all the excisions of the epiphyseal cartilage a piece of adjoining epiphyseal and diaphyseal bone was removed so as not to injure that particular region. Heller, in a postscript to his article, stated that he had succeeded in transplanting the epiphyseal cartilage in the form of very thin sheets of cartilage and that there resulted almost a normal growth. He does not give the exact details of his experiments, but from the results of my experiments I am forced to entertain some doubt as to the correctness of his conclusions. It is possible that by some special method he is able to get these good results.

\section{THE RELATION OF THE ROENTGEN- OLOGIST TO THE HOSPITAL *}

\section{H. W. VAN ALLEN, M.D. SPŔINGFIELD, MASS.}

The reason for presenting a paper dealing with the relation of the roentgenologist and the hospital comes from the very great variation of such relation at present. Were any one of the methods now in vogue approaching idealism, it would be shown by the number adopting such a method; while a study seems to show greater variation as time goes on. My attention was first called to this subject by the investigation made by a state committee in regard to patients coming to hospitals under the Massachusetts workmen's compensation act. This investigation showed no two institutions in the entire commonwealth making arrangements that could by any means be called similar. In medicine a multiplicity of drugs recommended for a particular disease shows a competency of none, and so it is fair to suppose the roentgenologist and the hospitals have not yet found a satisfactory arrangement one with the other.

The growth of the applications of the Roentgen ray is responsible for this condition. When first given to the medical profession, it promised to be one of the most limited specialties. The locating of dense foreign bodies and fractures of the bones of the extremities was its entire field. Now I say without hesitation there is no broader specialty in medicine. I cannot think of a single branch of the profession which does not call the Roentgen ray to its aid at times. Any medical journal is proof of the wide scope of this specialty, and more than half the articles show the dependence placed on the ray, either in diagnosis or in treatment.

The original roentgenologist was usually a photographer, electrician or a young and budding physician, hoping to use this as a stepping-stone to something more tangible. It was the way this original work was done that to a certain extent is the fault of the present condition. Many hospital superintendents and not a few physicians have failed to keep pace with the Roentgen progress and know the kind

\footnotetext{
* Read before the Section on Hospitals at the Sixty-Sixth Annual
} Session of the American Medical Association, San Francisco, June, 1915. 